\title{
Effectiveness of microbial consortium on growth, yield, and intensity of withered disease (Fusarium oxysporum Schelecht) on garlic plants
}

\author{
Eti Heni Krestini ${ }^{1,2,}$ Ulya Rusmawati ${ }^{3}$ and Ani Susilawati ${ }^{4}$ \\ ${ }^{1}$ Vegetable Research Institute, Jl. Tangkuban Perahu No. 517 Lembang Bandung \\ ${ }^{2}$ Faculty of Agriculture, Padjadjaran University, J1. Bandung Raya Sumedang KM 21, Jatinangor, Sumedang \\ ${ }^{3}$ Islam Nusantara Bandung University, J1 Sukarno Hatta no 530 Bandung \\ ${ }^{4}$ Indonesian Swamp Agriculture Research Institute(ISARI), J1. Kebun Karet, Loktabat, Banjarbaru 70712, South Kalimantan
}

\begin{abstract}
Garlic is one of the horticultural products that is further developed in Indonesia, this is done as one of our efforts to increase the needs of meeting the needs of products that always rely on imports. The productivity of our garlic is still low, below 20 tons/ha. To improve this efficiency, technology development is needed, one of which is by using a microbial consortium. The utilization of the microbial consortium in garlic cultivation is still limited. This study examines the best benefits of the microbial consortium for growth (height, number of leaves) and yield quality (tuber diameter and yield) as well as its effect on the development of wilt disease caused by Fusarium oxysporum Schelecht. The research was conducted at the Vegetable Crops Research Institute (Balitsa) from August to November 2018 using a Randomized Block Design consisting of 6 preparations and 4 replications. The approved microbial treatments were P0 (Control), P1 (12.5 g/plant), P2 (25 g/plant), P3 (50 g/plant), P4 (100 g/plant), and P5 (150) g/plant). The results showed that the use of $150 \mathrm{gr}$ microbial consortium showed the highest value for high plant parameters, while for the number of leaves, yield weight, tuber diameter did not show differences between workmanship. The influence of the use of a microbial consortium can control fusarium disease at 40 days after planting (HST) of 14.741.17 percent compared with control management.
\end{abstract}

\section{Introduction}

Garlic (Allium sativum L.) is a horticultural plant that is widely consumed in the world. In addition to being widely used in food, this plant is also widely used in the health sector, namely as a medicinal ingredient. Indonesia as one of the countries with the most population in the world meets its need for garlic by import. The important development of Indonesian garlic in 20 years (1996-2016) fluctuated with a tendency to continue to increase. Raising awareness to reduce the importance of garlic makes garlic development in Indonesia encouraged. The average productivity of garlic in Indonesia is $8.83 \mathrm{t} / \mathrm{ha}$. However, the results showed that garlic was only 6.43 tons/ha. This is still far compared to the increase in garlic in China which reached $23.5 \mathrm{t} / \mathrm{ha}$. As a target, the consumption of garlic declared by the government is 20 tons/Ha [1]. The low productivity of garlic in Indonesia is a challenge for all parties to develop garlic cultivation technology to improve the quality of garlic. One of the technologies developed to improve crop yields by improving plant structure and fertility is to utilize a microbial consortium. The microbial consortium is a collection of microorganisms that form a community of a large number of different ones [2].

Liquid biofertilizers containing a microbial consortium such as microbial Azotobacter chroococcum, A.vinelandii, Azosprilium sp, Acinetobacter sp, Pseudomonas cepacia, Penicillium sp, and A. chroococcum can reduce the intensity of leaf blight on the mustard plants caused by Rhizoctonia solani by $25.644 \%$. The microbial consortium has also been tested and can suppress damping-off disease, fusarium wilt disease and bacterial wilt disease in chili plants, clubroot disease in cabbage plants, and base rot disease in shallots [3]. The results of Yanti [4] reported that the use of a microbial consortium (bio boost) in the cultivation of rice can be beneficial to improve soil fertility as a result of soil biochemical processes. Other research also shows that the use of microbial consortia can act as a biocontrol of plant pathogens, bioremediation, and triggers for plant growth (PGPR) [5].

This study aims to determine the effect of the best dose of the microbial consortium for growth (height, number of leaves) and quality of the crop (tuber diameter and yield) and its effect on the development of wilting caused by Fusarium oxysporum Schelecht.

\section{Materials and Methods}

\subsection{Time and Place}

The study was conducted in the Experimental Garden of Indonesian Vegetable Research Institute at an altitude of 1,300 $\mathrm{m}$ asl in Lembang - West Java - Indonesia from August to November 2018. 


\subsection{Procedures}

The study was arranged in a Randomized Block Design consisting of 6 treatments and 4 replications. The microbial consortium treatments tested were: P0 (Control), P1 (12.5 g/plant), P2 (25 g/plant), P3 (50 $\mathrm{g} /$ plant), P4 (100 g/plant), and P5 (150 g/plant). The microbial consortium formulation tested contained Bacillus subtilis, Trichoderma harzianum, $A$. chroococcum, and Pseudomonas cepacia in the solid form, formulation of this microbe consortium was then mixed with compost in a ratio of 1,9 and incubated for 2 weeks. The microbial consortium treatments tested were: P0 (Control), P1 (12.5 g/plant), P2 (25 g/plant), P3 (50 g/plant), P4 (100 g/plant), and P5 (150 g/plant).
Application of microbial consortium is done the day before planting, by way of being inserted into each planting hole following the tested treatment. The data obtained are then analyzed by the Tukey test (BNJ).

\section{Results and Discussion}

Observation of the number of leaves and height of the garlic plant (A. sativum) was carried out at 68 and 82 days after planting (HST). The results of the study of the effect of microbial consortium treatment on plant height of garlic completely are presented in Table 1 .

Table 1. The number of leaves and height of the garlic plant (A. sativum L.).

\begin{tabular}{ccccc}
\hline \multirow{2}{*}{ Treatment } & \multicolumn{2}{c}{ Number of Leaves } & \multicolumn{2}{c}{ Plant height } \\
& 68 HST & $82 \mathrm{HST}$ & $68 \mathrm{HST}$ & $82 \mathrm{HST}$ \\
\hline P0 & $5.65 \mathrm{a}$ & $6.00 \mathrm{a}$ & $31.08 \mathrm{c}$ & $33.10 \mathrm{~b}$ \\
P1 & $5.70 \mathrm{a}$ & $6.05 \mathrm{a}$ & $31.84 \mathrm{c}$ & $33.76 \mathrm{ab}$ \\
P2 & $6.40 \mathrm{a}$ & $6.95 \mathrm{a}$ & $33.25 \mathrm{bc}$ & $34.32 \mathrm{ab}$ \\
P3 & $5.75 \mathrm{a}$ & $6.30 \mathrm{a}$ & $32.97 \mathrm{bc}$ & $34.59 \mathrm{ab}$ \\
P4 & $5.90 \mathrm{a}$ & $6.40 \mathrm{a}$ & $34.82 \mathrm{ab}$ & $35.41 \mathrm{ab}$ \\
P5 & $5.70 \mathrm{a}$ & $6.25 \mathrm{a}$ & $35.88 \mathrm{a}$ & $35.68 \mathrm{a}$ \\
\hline
\end{tabular}

Note:

- Numbers followed by the same letters in the same column show no significantly different based on the Duncan multiple distance test at 5\% significance level

- HST = Days after Planting

Based on Duncan's test analysis at 5\% significance level, the results of the analysis for the number of leaves parameters between the test treatments were not significantly different whereas for plant height parameters the use of a $150 \mathrm{~g}$ microbial consortium/plant showed the best growth and was different from the control treatment. Between control treatments (P0) with P1, P2, P3, and P4 at 82 HST did not show any difference. This was thought to be due to the influence of environmental factors that did not support microbial development and garlic growth. When the research was conducted to coincide with the peak of the dry season, the environmental conditions at that time were less conducive to the development of microbes and garlic, although watering was done every day so that the impact on garlic growth was less than optimal. This is supported by the results of previous studies which suggest that plant growth during the dry season tends to grow more slowly [6].

Temperature and humidity can also affect the development of microbes in the soil, temperatures that tend to be hot cause the speed of microbial metabolism to slow down, even cell components can become inactive and damaged so that cells become dead and nutrients in the microbes are reduced [7]. The research took place at the peak of the dry season so that plants and microbes were in high-temperature environmental conditions, and in drought stress, but even though the environmental conditions were not optimal the effectiveness of using microbes on garlic growth had a positive impact. This could be seen from the tendency of values in the parameters the number of leaves and plant height with microbial treatment showed a higher tendency compared to the control treatment (without microbial).

The effect of microbial treatment on garlic yields is shown in Table 2. The results of this study indicate an increase in garlic yield weight in all treatments of the addition of the test microbial consortium compared with control treatments even though the results of statistical tests are not different. Microbial treatment can increase the percentage of wet weight yields of $17-42.58 \%$ while the percentage increase in dry weight $23.87-45.67 \%$ compared with control treatments. Increased tuber diameter and the number of cloves in the microbial consortium treatment also occurred (Table 3). The results of this study indicate an increase in tuber diameter in the microbial consortium treatment by $12 \%$ and an increase in the number of cloves by 4.76 $26.19 \%$. The treatment of $25 \mathrm{~g} / \mathrm{plant}$ can increase the tuber diameter and the number of the best crop cloves compared with other treatments. 
Table 2. Garlic harvest results

\begin{tabular}{ccccc}
\hline Treatment & $\begin{array}{c}\text { Wet Weight } \\
(\mathrm{g})\end{array}$ & Dry Weight $(\mathrm{g})$ & $\begin{array}{c}\text { Tuber Diameter } \\
(\mathrm{mm})\end{array}$ & $\begin{array}{c}\text { Number of } \\
\text { cloves }\end{array}$ \\
\hline P0 & $251.25 \mathrm{a}$ & $144.50 \mathrm{a}$ & $22.01 \mathrm{a}$ & $4.20^{\mathrm{b}}$ \\
P1 & $294.00 \mathrm{a}$ & $179.00 \mathrm{a}$ & $22.13 \mathrm{a}$ & $4.40_{\mathrm{ab}}$ \\
P2 & $358.25 \mathrm{a}$ & $210.50 \mathrm{a}$ & $24.71 \mathrm{a}$ & $5.30^{\mathrm{a}}$ \\
P3 & $313.50 \mathrm{a}$ & $190.75 \mathrm{a}$ & $23.37 \mathrm{a}$ & $4.80^{\mathrm{ab}}$ \\
P4 & $324.50 \mathrm{a}$ & $197.50 \mathrm{a}$ & $23.65 \mathrm{a}$ & $5.00^{\mathrm{ab}}$ \\
P5 & $299.75 \mathrm{a}$ & $184.75 \mathrm{a}$ & $22.59 \mathrm{a}$ & $4.70^{\mathrm{ab}}$ \\
\hline
\end{tabular}

Application of microbial consortium in garlic plants in addition to influencing growth and yield also affected the suppression of fusarium wilt disease intensity (Table 3). The intensity of fusarium wilt disease in the control treatment was higher than the treatment of the microbial consortium. This illustrates that the administration of the microbial consortium was able to suppress the development of the disease, especially fusarium wilt disease in garlic with a decreasing percentage of $14.7-41.17 \%$ and $25 \mathrm{~g}$ treatment/plant showed the highest decrease in intensity of fusarium wilt.

Table 3. Results of analysis of average intensity

symptoms of Fusarium withered disease on garlic (A. sativum).

\begin{tabular}{cc}
\hline Treatments & Disease Intensity $(40$ DAP*) \\
\hline P0 & $17.00 \mathrm{a}$ \\
P1 & $13.00 \mathrm{ab}$ \\
P2 & $10.00 \mathrm{~b}$ \\
P3 & $14.50 \mathrm{ab}$ \\
P4 & $14.00 \mathrm{ab}$ \\
P5 & $13.00 \mathrm{ab}$ \\
\hline
\end{tabular}

*Day After Plant

Onion plants require the availability of macronutrients, especially nitrogen $(\mathrm{N})$, phosphorus $(\mathrm{P})$, and potassium $(\mathrm{K})$ insufficient and balanced amounts, both from inorganic fertilizers and organic fertilizers [8]. Fertilization with a microbial consortium can provide nutrients both macro and micro and help improve the development of soil microorganisms which then regulate nutrient availability. This is reinforced based on the results of research Kalay [9] which states that the microbial consortium can increase plant height growth with nitrogen fixation bacterial content by providing $\mathrm{NH}^{3}$ and subsequently converted to $\mathrm{NH}^{4+}$ and $\mathrm{NO}^{3-}$. Nitrogen, phosphorus, and potassium nutrient needs that are fulfilled can affect the total microbial population in the soil. the microbial consortium can produce auxin, cytokinin, and gibberellin phytohormones which support the growth and quality of crop production [10]. The microbial consortium in addition to influencing the growth and quality of crop yields also influences the resistance to plant diseases. The microbial consortium can inhibit the growth of plant pathogens [11]. It is because in the microbial consortium there are microbes that are antagonistic and can produce antibiotics such as Pseudomonas which can produce antibiotics such as phenazines, pyrolnitrin, pyocyanin, phloroglucinol and pseudomonic acid [12].

\section{Conclusion}

Microbial consortium formulations used in this study contain B. subtilis, T. harzianum, A. chroococcum, and $P$. cepacia and are proven to be able to increase plant height growth, increase garlic yields and can suppress the intensity of fusarium wilt ( $F$. oxysporum) on garlic plants and are proven to be able to increase plant height growth, increase garlic yields and can suppress the intensity of fusarium wilt disease (F. oxysporum).

We would like to thank all those who helped with the completion of this research activity including Kujang Fertilizer who has facilitated the availability of a microbial consortium and NPK fertilizer and UIN students (sisters Erna and Anna) who helped a lot in carrying out this research.

\section{References}

1. Kementerian Pertanian. Syarat Tumbuh Bawang Putih (Online). http : //www.pertanian.go.id, (2017)

2. Nugraha \& Hidayah. Pengertian Konsorsium Mikroba (Online). http : //ftsl.itb.ac.id.sites, (2010)

3. Prihatiningsih. Manfaat Mikroba Bacillus subtilis (Online). http://oseanografi.lipi.go.id >dokumen (2015)

4. F. Yanti. Peranan Bakteri Azospirillum sp (Online). http: //anzdoc.com/tinjauan-pustaka-azospirillumsp.html, (2014)

5. Coenye \& Vandamme. Jenis Mikroba Yang Tergolong PGPR (Online). http ://biodiversitas.mipa.uns.ac.id (2003)

6. Damanik, H. Hanum, \& Nurhayati. Faktor-Faktor Penyebab Tanaman Tumbuh Lambat (Online). http://brainly.co.id (2013)

7. Sortiningsih. Perkembangan Mikroba (Online). http ://biosains.mipa.uns.ac.id, (2009)

8. A. Suprapto, M. Astiningrum, \& H. Rianto. Optimalisasi Dosis pupuk NPK dan Pupuk Organik Cair untuk Produksi Bawang Merah di Lahan Pasca Erupsi Merapi, (2018)

9. A.M. Kalay, R. Hindersah, A. Talahaturuson, A.F. Langoi. Efek Pemberian Pupuk Hayati Konsorsium terhadap Pertumbuhan dan Hasil Tanaman Sawi 
(Brassica juncea L.). Jurnal Agroekoteknologi. 8 (2): $131-138,(2016)$

10. A. Hendriyana. PT Pupuk Kujang Produksi Pupuk Hayati Bion-Up Karya UNPAD. http://www.unpad.ac.id/2014/12/pt-pupuk-kujangproduksi-pupuk-hayati-bion-karya-unpad/ (2014)

11. F. Yanti. Aplikasi Konsorsium Bakteri terhadap Pertumbuhan dan Hasil Pada Beberapa Varietas Padi. Skripsi. Universitas Jember. Jember, (2015)

12. P.M. B. Iskandar \& S. Purwantisari. Kemampuan Antagonisme Pseudomonas sp. dan Penicillium sp. terhadap Cercospora nicotianae In Vitro. Jurnal Biologi, 7 (3): 1 - 7, (2018) 